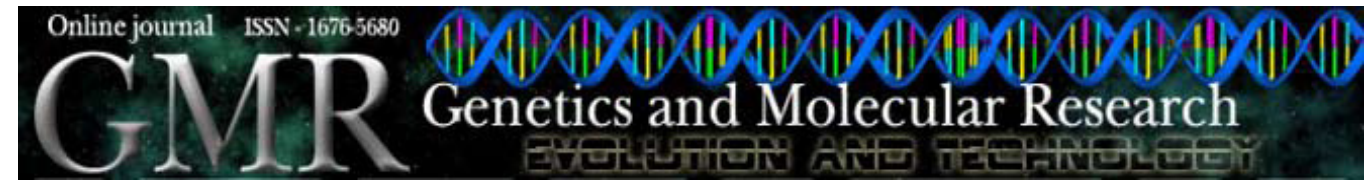

\title{
Morphometric and genetic changes in a population of Apis mellifera after 34 years of Africanization
}

T.M. Francoy ${ }^{1}$, D. Wittmann ${ }^{2}$, V. Steinhage ${ }^{3}$, M. Drauschke ${ }^{3}$, S. Müller ${ }^{3}$, D.R. Cunha ${ }^{4}$, A.M. Nascimento ${ }^{5}$, V.L.C. Figueiredo ${ }^{5}$, Z.L.P. Simões ${ }^{5}$, D. De Jong ${ }^{1}$, M.C. Arias ${ }^{4}$ and L.S. Gonçalves ${ }^{5}$

${ }^{1}$ Departamento de Genética, Faculdade de Medicina de Ribeirão Preto, Universidade de São Paulo, Ribeirão Preto, SP, Brasil

${ }^{2}$ Institut für Nutzpflanzenwissenschaften und Ressourcenschutz, Universität Bonn, Bonn, Germany

${ }^{3}$ Institut für Informatik III, Universität Bonn, Bonn, Germany

${ }^{4}$ Departamento de Genética e Biologia Evolutiva, Instituto de Biociências, Universidade de São Paulo, São Paulo, Brasil ${ }^{5}$ Departamento de Biologia, Faculdade de Filosofia,

Ciências e Letras de Ribeirão Preto, Universidade de São Paulo,

Ribeirão Preto, SP, Brasil

Corresponding author: T.M. Francoy

E-mail: tfrancoy@rge.fmrp.usp.br

Genet. Mol. Res. 8 (2): 709-717 (2009)

Received December 12, 2008

Accepted January 26, 2009

Published June 16, 2009

ABSTRACT. Though the replacement of European bees by Africanized honey bees in tropical America has attracted considerable attention, little is known about the temporal changes in morphological and genetic characteristics in these bee populations. We examined the changes in the morphometric and genetic profiles of an Africanized honey bee population collected near where the original African swarms escaped, after 34 years of Africanization. Workers from colonies sampled in 1968 and in 2002 were morphometrically analyzed using relative warps analysis and an Automatic Bee Identification System (ABIS). All the colonies had 
their mitochondrial DNA identified. The subspecies that mixed to form the Africanized honey bees were used as a comparison for the morphometric analysis. The two morphometric approaches showed great similarity of Africanized bees with the African subspecies, Apis mellifera scutellata, corroborating with other markers. We also found the population of 1968 to have the pattern of wing venation to be more similar to A. m. scutellata than the current population. The mitochondrial DNA of European origin, which was very common in the 1968 population, was not found in the current population, indicating selective pressure replacing the European with the African genome in this tropical region. Both morphometric methodologies were very effective in discriminating the A. mellifera groups; the non-linear analysis of ABIS was the most successful in identifying the bees, with more than $94 \%$ correct classifications.

Key words: Apis mellifera; Species identification; Wing morphometrics; Biodiversity; mtDNA;

Geometric morphometrics

\section{INTRODUCTION}

After the swarms of 26 colonies of the African honey bee Apis mellifera scutellata escaped in Brazil in 1957, they became established as feral colonies and initiated a series of crosses and backcrosses with the previously introduced European honey bee races. This hybridization process resulted in the Africanized honey bee (Kerr, 1967; Sheppard et al., 1991a,b; Clarke et al., 2002). Despite being very well adapted to life in tropical conditions, and having desirable characteristics for beekeeping, such as high honey production, great adaptability, accentuated hygienic behavior, and resistance to brood diseases, the Africanized honey bees also had some undesirable traits. These included strong swarming tendencies and highly developed defensive behavior (Gonçalves, 1974), which lead many beekeepers to abandon their activities in Brazil at the beginning of the Africanization process. Time and research modified this scenario and Brazilian beekeeping has totally recuperated and is in a strong development phase (Gonçalves, 2004).

The new introduced bees rapidly spread in all the directions from Rio Claro in São Paulo State, colonizing most of South America and all of Central America, reaching the USA in 1990. Currently, they occupy parts of the States of Texas, California, Arizona, Nevada, and New Mexico in the USA (Sheppard et al., 1999; Pinto et al., 2005).

Though the initial swarms escaped in 1957, the first published studies on the Africanized honey bees appeared in the mid 60's. Kerr et al. (1967) and Gonçalves (1970) reported on their biology, morphology and behavior. Subsequent research focused on their identification by morphometrics (Daly and Balling, 1978; Daly et al., 1982), allozymes (Contel et al., 1977; Martins et al., 1977) and DNA analysis (Hall, 1986; Smith and Brown, 1988; Hall and Muralidharan, 1989; Smith et al., 1989).

Currently, much is known about the genetic status of Africanized honey bee populations in the Americas and the degree of Africanization in most of the countries where these 
bees are found (Kerr et al., 1982; Lobo et al., 1989; Sheppard et al., 1991a, 1999; Pérez-Castro et al., 2002; Clarke et al., 2002; Diniz et al., 2003; Quezada-Euán et al., 2003).

However, the genetic and morphometric profiles of the bees at the beginning of the Africanization process in Brazil were not well documented. The initial studies had more practical objectives, including identification and basic biology; it was very important to learn how to handle these bees.

Using two different morphometric approaches and molecular analysis we examined the initial Africanized honey bee population based on specimens collected 1965-1968 and compared with $A$. m. scutellata and with the current Africanized population.

\section{MATERIAL AND METHODS}

The main honey bee subspecies introduced into Brazil were used as founder populations in our analyses. Samples of Apis mellifera mellifera, Apis mellifera carnica, Apis mellifera ligustica, and Apis mellifera scutellata were obtained from the Morphometric Bee Data Bank in Oberursel, Germany; these samples cover a great part of the geographic distribution of these groups.

The Africanized honey bees were collected from Ribeirão Preto ( $\left.21^{\circ} 10^{\prime} \mathrm{S} 47^{\circ} 51^{\prime} \mathrm{W}\right)$, about $150 \mathrm{~km}$ from the introduction point of the original Apis mellifera scutellata queens. The first sample was collected from 1965 to 1968, at the beginning of the Africanization process and the second one was taken more than 30 years later, in 2002.

Samples of five workers were taken from 10 different colonies. The right forewing of each individual was placed between microscope slides and photographed with a digital camera attached to a stereomicroscope.

Two different methods were used for the morphometric analyses. One is based on geometric morphometrics and the other is a fully automated image analysis system used for bee species identification (ABIS) (Francoy et al., 2008).

The geometric morphometric analysis was made by manually plotting 19 homologous landmarks at wing vein intersections using the software tpsDig version 2.04 (Rohlf, 2005a); these images were Procrustes aligned (Bookstein, 1991). A relative warp analysis was carried out using the software tpsRelw version 1.42 (Rohlf, 2005b) with $\alpha$ set to 0 in order to give the same weight to all variables. Significant univariate F-values $(\alpha=0.05)$ identified the wing parameters that contributed most to discriminating the groups; a discriminant analysis was run to separate them. The Mahalanobis square distances among the populations were then used to construct a neighbor joining dendogram with the software MEGA version 2.1 (Kumar et al., 2001).

The automated software, ABIS, first performs a fully automated analysis of images of the bee forewings. The geometry and structure of these venation networks are used as fingerprints for bee species and subspecies (Roth et al., 1999; Steinhage et al., 2006). To identify these fingerprints derived from wing images, ABIS performs a statistical classification step. This classification is based on classical Fisher's linear discriminant analysis (LDA), which is adequate for genus identification. Alternatively, a far more powerful non-linear Kernel discriminant analysis (KDA; Roth and Steinhage, 1999) allows species or even subspecies identification. Both these classification methods are supervised classification methods, which need to be trained with at least 20 specimens of each class (species, race, population); these must be identified within the given application of ABIS. 
The DNA of one worker per colony from 18 different colonies of each of the two groups of Africanized bees (1968 and 2002) was extracted using the methodologies proposed by Philips and Simon (1995) and Innis et al. (1990). A 173-bp long fragment of Cyt B locus was amplified (Sheppard et al., 1994) using the following primers: CO1- 5' TTAACTGGATCATCTAATCC 3' and B11- 5' TGCAATTTTGAAATTGTCTG 3'. The product was digested with $B g l \mathrm{III}$. The $B g l \mathrm{II}$ site is diagnostic of European mitochondrial DNA origin; it is absent in African-derived mitochondrial genomes (Crozier et al., 1991). After digestion, the fragments were separated on $6 \%$ polyacrylamide gels and visualized with silver staining (Sanguinetti et al., 1994).

\section{RESULTS}

\section{Geometric morphometrics}

Among the 34 relative warps generated by the analysis, 31 contributed significantly ( $\mathrm{P}$ $<0.05$ ) to the separation of the six groups (A. m. ligustica, A. m. carnica, A. m. mellifera, A. $m$. scutellata, and the two Africanized samples). The first three relative warps explained $45.39 \%$ of the total data variability, $23.26 \%$ being explained by the first, $12.46 \%$ by the second and $9.67 \%$ by the third relative warp. Based on multivariate analyses of variance (MANOVA), significant differences were found among the groups (Wilk's $\lambda=0.00687$; $\mathrm{P}<0.0001$ ). Discriminant analysis of the Mahalanobis square distance (Table 1) between the centroids showed that each centroid was significantly different from all the others at $\mathrm{P}<0.0000001$, except for the centroid of the A. m. mellifera group, which was different at $\mathrm{P}<0.001$ from all the other centroids.

\begin{tabular}{|c|c|c|c|c|c|}
\hline & RP - 2002 & A. m. ligustica & RP - 1968 & A. m. mellifera & A. m. scutellata \\
\hline A. m. carnica & 37.68 & 9.32 & 32.98 & 34.54 & 27.08 \\
\hline RP - 2002 & & 34.04 & 12.43 & 24.18 & 15.14 \\
\hline A. m. ligustica & & & 29.83 & 29.68 & 23.65 \\
\hline RP - 1968 & & & & 21.60 & 12.40 \\
\hline A. m. mellifera & & & & & 22.47 \\
\hline
\end{tabular}

$\mathrm{RP}=$ Ribeirão Preto.

The linear discriminant functions calculated using the data from geometric morphometry were able to identify $85 \%$ in the leave-one-out test, while the cross-validation tests, using 10 and $20 \%$ of the individuals as unknowns, correctly classified 84.6 and $82.7 \%$, respectively.

Based on the neighbor-joining tree (Figure 1) constructed with the Mahalanobis square distances (Table 1), the subspecies of the C lineage (Ruttner, 1988), A. m. ligustica and A. m. carnica, were the closest to each other, forming a cluster. The A. m. scutellata (lineage A) and the two populations of Africanized honey bees were grouped together in another branch. In this "African" branch, the two Africanized populations were grouped together. Apis m. mellifera, which belongs to the M lineage, formed an isolated branch between the other two branches. 


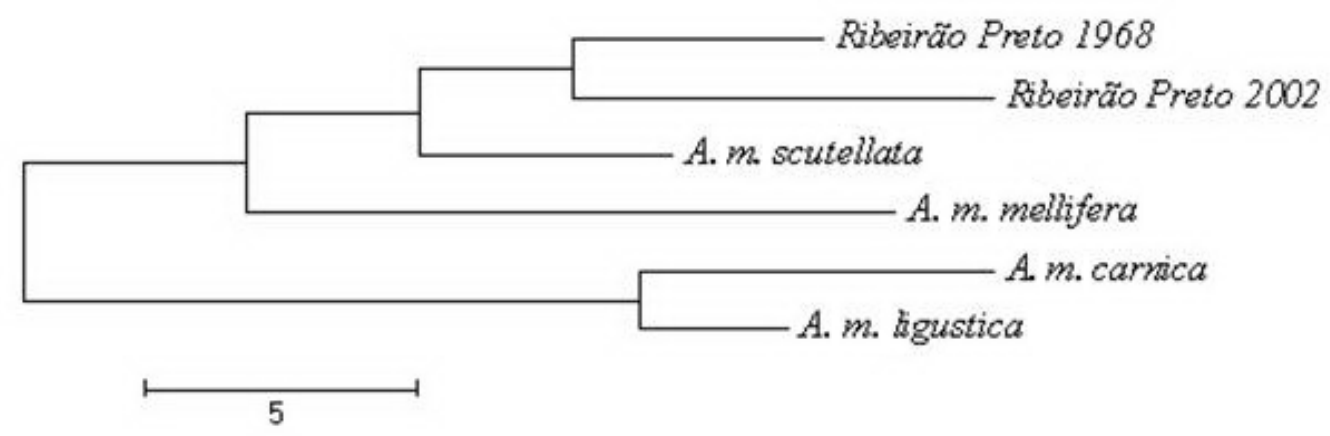

Figure 1. Dendogram of morphological proximity constructed using Mahalanobis square distances between the groups, calculated through relative warps analysis.

\section{ABIS}

Since ABIS is a completely automated system able to do two different discriminant processes, one based on linear discriminant analysis and one based on KDA, we used both methods. The linear discriminant functions correctly identified $83.6 \%$ of the samples in the leave-one-out test, while the cross-validation tests, using 10 and $20 \%$ of the individuals as unknowns correctly classified 81.4 and $75 \%$, respectively.

The neighbor-joining tree (Figure 2) constructed with the Mahalanobis square distances calculated from the values of the linear discriminant analysis of ABIS (Table 2) had a topology similar to that constructed with the geometric morphometrics data. The only change was that the subspecies A. m. ligustica and A. m. carnica from the $\mathrm{C}$ lineage were no longer in the same branch. According to this topology, the subspecies that are most distant from the Africanized populations are A. m. ligustica, followed by A. m. carnica and A. m. mellifera. The subspecies closest to the Africanized populations is A. m. scutellata.

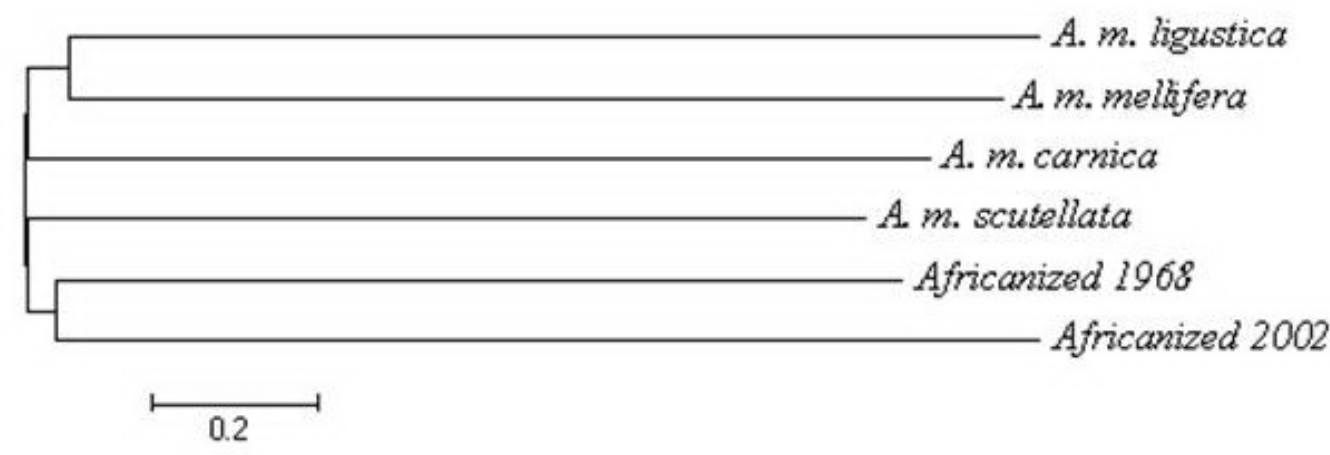

Figure 2. Dendogram of morphological proximity constructed with the distances calculated through linear discriminant analysis in ABIS. 


Table 2. Mahalanobis square distances between the centroids of the Apis mellifera groups calculated through
linear discriminant analysis using the software ABIS.
\begin{tabular}{lccccc}
\hline A. m. ligustica & A. m. carnica & A. m. scutellata & RP - 1968 & RP - 2002 \\
\hline A. m. mellifera & 2.32 & 2.29 & 2.12 & 2.16 & 2.34 \\
$\begin{array}{ll}\text { A. m. ligustica } \\
\text { A. m. carnica }\end{array}$ & 2.31 & 2.27 & 2.31 & 2.45 \\
A. m. scutellata & & 2.19 & 2.24 & 2.44 \\
RP - 1968 & & & 2.09 & 2.24 \\
\hline
\end{tabular}

$\mathrm{RP}=$ Ribeirão Preto.

When we used KDA, the classification rates were higher than with linear discriminant analysis. The Kernel discriminant functions were able to identify $94.1 \%$ of the individuals in the leave-one-out test, and 94 and $93.4 \%$, respectively, in the cross-validation tests, using 10 and $20 \%$ of the individuals as unknowns.

\section{Mitochondrial DNA}

The $B g l I I$ restriction site was found in seven of 18 Africanized colonies sampled in the 1960s, indicating European mitochondrial DNA origin. In the remaining colonies this restriction site was absent, indicating African-derived mitochondrial DNA. In contrast, the 18 colonies sampled in 2002 all had mitochondrial DNA of African origin.

\section{DISCUSSION}

Although traditional morphometrics is the basis of the current identification of all Apis mellifera subspecies, the new methods of automated measures and geometric morphometry had been used to distinguish or to characterize these groups in just a few recent works (Francoy et al., 2006a, 2008; Tofilski, 2008). The high correct classification rates that we found indicate that forewings carry sufficient information to distinguish the bee groups that we examined. Along with molecular analysis of mtDNA origin, the association of these methodologies was found to be very informative. We used these analyses together to examine whether a population of Africanized honey bees sampled the African bees first escaped in Brazil had changed after 35 years.

The two morphometric methodologies, though they used different principles for measuring the characteristics, gave similar dendogram topologies. A comparison of the dendogram constructed based on geometric morphometrics with dendograms constructed by ABIS is only reasonable with the ABIS dendogram constructed from LDA, since both are linear. As the KDA applies non-linear analyses, it is hard to compare results. This is the reason we used the LDA, since we found that KDA is much better at identifying the individuals, corroborating results from other studies using ABIS (Drauschke et al., 2007; Steinhage et al., 2007; Francoy et al., 2008).

Nevertheless, the Africanized populations were always closer to each other in all the dendrograms. The Mahalanobis distances calculated from both methodologies demonstrated strong similarity of the two Africanized populations. These two groups were always more similar to A. m. scutellata (A branch), indicating that the patterns of wing venation of Africanized bees are greatly influenced by this subspecies. Other studies also emphasized this close relationship (Lobo et al., 1989; Del Lama et al., 1990; Lobo and Krieger, 1992; Clarke 
et al., 2002; Quezada-Euán et al., 2003; Whitfield et al., 2006). Overall, A. m. mellifera (M branch) was the European subspecies that was closest to the Africanized populations; $A$. $m$. ligustica and A. m. carnica (C branch) were more distant. A previous study based on $M d h$ isozyme systems (Lobo et al., 1989) found 80 to $85 \% \mathrm{~A}$. m. scutellata alleles for this locus and 12 to $15 \%$ A. m. mellifera alleles in Africanized bees in São Paulo State. Although we cannot quantify the morphological influence of each subspecies in our two Africanized populations, the data suggest the same ranking of A. m. scutellata and A. m. mellifera as contributing subspecies. Other studies made in other regions of South and Central America showed similar patterns of genetic composition (Contel et al., 1977; Del Lama et al., 1990; Sheppard et al., 1991a; Lobo and Krieger, 1992; Whitfield et al., 2006).

The weaker influence of $A$. m. ligustica and A. m. carnica in relation to the other subspecies, at least for nuclear genes, is also reflected in the Mahalanobis square distances and in the neighbor-joining tree. Similar findings came from studies using other genetic markers (Contel et al., 1977; Lobo et al., 1989; Del Lama et al., 1990; Sheppard et al., 1991a; Lobo and Krieger, 1992). It was recently demonstrated (Francoy et al., 2006b) that the pattern of wing venation of Africanized bees is genetically dominant over that of Italian bees; our analysis of the more recent Africanized bee population reinforce this idea, since the influence of $A$. $m$. ligustica was extremely weak, even though many queens were introduced in an attempt to reduce the impact of the Africanized bees (Gonçalves, 1974).

The proximity of A. m. mellifera with the "African" group could be a reflex of the greater proximity of the bees from the "A" and "M" branches proposed by Ruttner (1988) to each other than when compared with the "C" branch, as recently demonstrated by single-nucleotide polymorphism analysis (Whitfield et al., 2006).

The absence of European-derived mtDNA in the current population, indicating complete substitution of the European queens in the population would also help to explain the greater proximity of the Africanized bees to the A. m. scutellata group. Even with the distribution of more than 23,000 A. m. ligustica queens to the beekeepers at the beginning of the Africanization process (Gonçalves, 1974) there was apparently no impact on the established population in 2002. This substitution of mitotypes seems to be very common in the regions occupied by Africanized bees (Del Lama et al., 1990; Sheppard et al., 1991a,b; Clarke et al., 2002; Collet et al., 2006), except for some places where the climate is more favorable to the European races, such as at high altitudes (Quezada-Euán et al., 2003) and near the borders of the distribution of these bees (Sheppard et al., 1999; Pinto et al., 2005). This fact could be explained by several mechanisms, such as usurpation of European colonies by Africanized swarms (Vergara et al., 1993) and disadvantage of hybrids with European maternity (Harrison and Hall, 1993; Schneider et al., 2004).

The changes in the wing venation clearly indicate that Africanized honey bees continued to differentiate in the period from 1968 to 2002 . The Mahalanobis square distances clearly show that the distance between the Africanized population and all the other subspecies increased considerably between 1968 and 2002. Thus, the current populations of Africanized bees have evolved a unique profile, different from the subspecies that originated these bees.

Both morphometric methodologies were efficient in the discrimination of the groups, although the best classification rates were achieved using the non-linear discriminant analysis of ABIS, which correctly classified more than $94 \%$ of the individuals in each respective group. These results are very promising because the current methods of classification of Apis mellifera subspecies are normally much more time consuming; identification with ABIS takes 
no more than $3 \mathrm{~min}$. We are now concentrating our efforts on establishing new protocols to facilitate this identification, using both geometric morphometrics and ABIS.

\section{ACKNOWLEDGMENTS}

We dedicate this manuscript to Prof. Dr. Warwick Estevam Kerr. Research supported by FAPESP, CAPES and CNPq. We also thank Dr. Stefan Fuchs for the Apis mellifera samples.

\section{REFERENCES}

Bookstein FL (1991). Morphometric Tools for Landmark Data. Cambridge University Press, Cambridge.

Clarke KE, Rinderer TE, Franck P, Quezada-Euan JG, et al. (2002). The Africanization of honeybees (Apis mellifera L.) of the Yucatan: a study of a massive hybridization event across time. Evolution 56: 1462-1474.

Collet T, Ferreira KM, Arias MC, Soares AE, et al. (2006). Genetic structure of Africanized honeybee populations (Apis mellifera L.) from Brazil and Uruguay viewed through mitochondrial DNA COI-COII patterns. Heredity 97: 329-335.

Contel EP, Mestriner MA and Martins E (1977). Genetic control and development expression of malate dehydrogenase in Apis mellifera. Biochem. Genet. 15: 859-876.

Crozier YC, Koulianos S and Crozier RH (1991). An improved test for Africanized honeybee mitochondrial DNA. Experientia 47: 968-969.

Daly HV and Balling SS (1978). Identification of Africanized honeybees in the Western Hemisphere by discriminant analysis. J. Kans. Entomol. Soc. 51: 857-869.

Daly HV, Hoelmer K, Norman P and Allen T (1982). Computer assisted measurement and identification of honey bees. Ann. Entomol. Soc. Am. 75: 591-594.

Del Lama MA, Lobo JA, Soares AEE and Del Lama SN (1990). Genetic differentiation estimated by isozymic analysis of Africanized honeybee population from Brazil and from Central America. Apidologie 21: 271-280.

Diniz NM, Soares AEE, Sheppard WS and Del Lama MA (2003). Genetic structure of honeybee populations from southern Brazil and Uruguay. Genet. Mol. Biol. 26: 47-52.

Drauschke M, Steinhage V, Pogoda A, Müller S, et al. (2007). Reliable Biometrical Analysis in Biodiversity Information Systems. In: 7th International Workshop on Pattern Recognition in Information Systems, Madeira, Portugal, 23-36.

Francoy TM, Prado PRR, Gonçalves LS, Da Fontoura Costa L, et al. (2006a). Morphometric differences in a single wing cell can discriminate Apis mellifera racial types. Apidologie 37: 91-97.

Francoy TM, Gonçalves LS, De Jong D and Wittmann D (2006b). Wing venation of Africanized honey bees is dominant over European. Apidologie 37: 597-598.

Francoy TM, Wittmann D, Drauschke M, Müller S, et al. (2008). Identification of Africanized honey bees through wing morphometrics: two fast and efficient procedures. Apidologie 39: 488-494.

Gonçalves LS (1970). Análise Genética do Cruzamento entre Apis mellifera ligustica e Apis mellifera adansonii. Escolha e Análise Genética de Caracteres Morfológicos da Cabeça e do Tórax. Doctoral thesis, Faculdade de Medicina de Ribeirão Preto, Universidade de São Paulo, Ribeirão Preto.

Gonçalves LS (1974). The introduction of the African Bees (Apis mellifera adansonii) into Brazil and some comments on their spread in South America. Am. Bee J. 114: 414-419.

Gonçalves LS (2004). The Big Challenge: Development of Beekeeping with Africanized Honey Bees in Northeast Brazil. In: Proceedings of the 8th IBRA International Conference on Tropical Bees and VI Encontro sobre Abelhas, Ribeirão Preto, Brasil, September 6-10, 2004 (Hartfelder K, De Jong D, Pereira RA, dos Santos Cristino A, et al., eds.). FUNPEC Editora, Ribeirão Preto, 241-246.

Hall HG (1986). DNA differences found between Africanized and European honeybees. Proc. Natl. Acad. Sci. U. S. A. 83: 4874-4877.

Hall HG and Muralidharan K (1989). Evidence from mitochondrial DNA that African honey bees spread as continuous maternal lineages. Nature 339: 211-213.

Harrison JF and Hall HG (1993). African-European honeybee hybrids have low nonintermediate metabolic capacities. Nature 363: 258-260.

Innis MA, Gelfand DH, Sninsky JJ and White TJ (1990). PCR Protocols. Academic Press, San Diego.

Kerr WE (1967). The history of the introduction of Africanized honey bees to Brazil. S. Afr. Bee J. 39: 3-5.

Kerr WE, Gonçalves LS, Stort AC and Bueno D (1967). Biological and genetical information on Apis mellifera adansonii. 
In: Proceedings of the 21st International Apicultural Congress APIMONDIA, Maryland, 76.

Kerr WE, Del Rio SL and Barrionuevo MD (1982). The southern limits of the distribution of the Africanized honey bee in South America. Am. Bee J. 122: 196-198.

Kumar S, Tamura K, Jakobsen IB and Nei M (2001). MEGA2: molecular evolutionary genetics analysis software. Bioinformatics 17: 1244-1245.

Lobo JA and Krieger H (1992). Maximum likelihood estimates of gene frequencies and racial admixture in Apis mellifera L. (Africanized honeybees). Heredity 68: 441-448.

Lobo JA, Del Lama MA and Mestriner MA (1989). Population differentiation and racial admixture in the Africanized honeybee (Apis mellifera L.). Evolution 43: 794-802.

Martins E, Mestriner MA and Contel EP (1977). Alcohol dehydrogenase polymorphism in Apis mellifera. Biochem. Genet. 15: 357-366.

Pérez-Castro EE, May-Itzá WJ and Quezada-Euán JJG (2002). Thirty years after: a survey on the distribution and expansion of Africanized honey bees (Apis millifera) in Peru. J. Apic. Res. 41: 69-73.

Phillips AJ and Simon C (1995). Simple, efficient, and nondestructive DNA extraction protocol for arthropods. Ann. Entomol. Soc. Am. 88: 281-283.

Pinto MA, Rubink WL, Patton JC, Coulson RN, et al. (2005). Africanization in the United States: replacement of feral European honeybees (Apis mellifera L.) by an African hybrid swarm. Genetics 170: 1653-1665.

Quezada-Euán JJG, Pérez-Castro EE and May-Itzá WJ (2003). Hybridization between European and African-derived honeybee populations (Apis mellifera) at different altitudes in Peru. Apidologie 34: 217-225.

Rohlf FJ (2005a). tpsDig, Version 2.04. Department of Ecology and Evolution. State University of New York, Stony Brook.

Rohlf FJ (2005b). tpsRelw, Version 1.42. Department of Ecology and Evolution. State University of New York, Stony Brook.

Roth V and Steinhage V (1999). Nonlinear Discriminant Analysis Using Kernel Functions. In: Advances on Neural Information Processing Systems, NIPS 12, Denver (Colorado), November 30-December 2, 1999 (Solla SA, Leen TK and Mueller KR, eds.). Denver, 568-574.

Roth V, Pogoda A, Steinhage V and Schröder S (1999). Integrating Feature-Based and Pixel-Based Classification for the Automated Identification of Solitary Bees. 21. Jahrestagung der Deutschen Gesellschaft für Mustererkennung, DAGM '99, Bonn, Sept. 15-17, 1999. Informatik aktuell, 120-129.

Ruttner F (1988). Biogeography and Taxonomy of Honeybees. Springer, Berlin.

Sanguinetti CJ, Dias NE and Simpson AJ (1994). Rapid silver staining and recovery of PCR products separated on polyacrylamide gels. Biotechniques 17: 914-921.

Schneider SS, Deeby T, Gilley DC and DeGrandi-Hoffman G (2004). Seasonal nest usurpation of European colonies by African swarms in Arizona, USA. Insectes Soc. 51: 359-364.

Sheppard WS, Soares AEE, De Jong D and Shimanuki H (1991a). Hybrid status of honey bee populations near the historic origin of Africanization in Brazil. Apidologie 22: 643-652.

Sheppard WS, Rinderer TE, Mazzoli J, Stelzer JA, et al. (1991b). Gene flow between African- and European-derived honey bee populations in Argentina. Nature 349: 782-784.

Sheppard WS, Arias MC and Shimanuki H (1994). Determination of mitochondrial DNA haplotypes from sting remnants of the honeybee Apis mellifera (Hymenoptera: Apidae). Bull. Entomol. Res. 84: 551-554.

Sheppard WS, Rinderer TE, Garnery L and Shimanuki H (1999). Analysis of Africanized honey bee mitochondrial DNA reveals further diversity of origin. Genet. Mol. Biol. 22: 73-75.

Smith DR and Brown WM (1988). Polymorphisms in mitochondrial DNA of European and Africanized honeybees (Apis mellifera). Experientia 44: 257-260.

Smith DR, Taylor OR and Brown WM (1989). Neotropical Africanized honey bees have African mitochondrial DNA. Nature 339: 213-215.

Steinhage V, Schröder S, Roth V, Cremers AB, et al. (2006). The science of "Fingerprinting" bees. German Res. 28: 19-21.

Steinhage V, Schröder S, Lampe KH and Cremers AB (2007). Automated Extraction and Analysis of Morphological Features for Species Identification. In: Automated Object Identification in Systematics: Theory, Approaches, and Applications. The Systematics Association Special Volume Series 74 (MacLeod N, ed.). CRC Press, Taylor \& Francis Group, London, 8: 115-129.

Tofilski A (2008). Using geometric morphometrics and standard morphometry to discriminate three honeybee subspecies. Apidologie 39: 558-563.

Vergara C, Dretz A and Percz de Leon A (1993). Female parasitism of European honey bees by Africanized honey bee swarms in Mexico. J. Apic. Res. 32: 34-40.

Whitfield CW, Behura SK, Berlocher SH, Clark AG, et al. (2006). Thrice out of Africa: ancient and recent expansions of the honey bee, Apis mellifera. Science 314: 642-645. 